Standards-based reform and students with disabilities: Reflections on a decade of change

Thurlow, Martha L

Focus on Exceptional Children; Nov 2000; 33, 3; Research Library

pg. 1

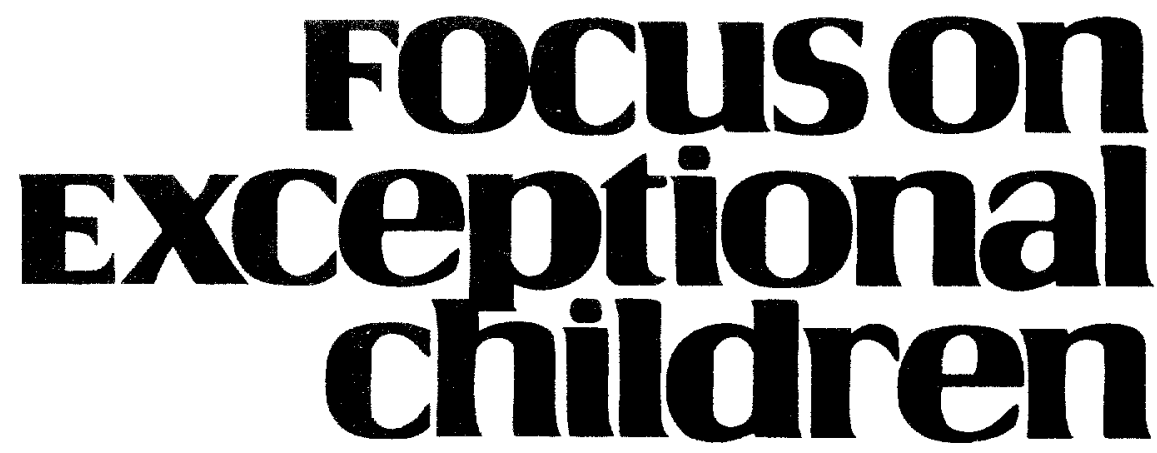

\title{
Standards-Based Reform and Students with Disabilities: Reflections on a Decade of Change
}

\author{
Martha L. Thurlow
}

Calls for higher and more rigorous standards for all students turned out to be the educational battle cry of the 1990 s. State after state defined its content and performance standards, and a major push for change in education became known as "standards-based reform." Near the beginning of standards-based reform, special educators asked whether all students, in particular students with disabilities or the individuals who worked with them, were included in various aspects of the reform-setting standards, developing assessments, taking tests, getting data on test results, and so on.

Nearly a decade has now passed. What has happened? What has standards-based reform meant for students with disabilities? These questions are important to answer because the push for standards-based education continues to make the headlines and to be pushed forward by federal and state initiatives. I hope to answer the questions about where we are now in standards and standards-based reforms for students with disabilities.

First, I provide a brief history of standards and what standards-based reform has entailed. Then I describe what has occurred in including students with disabilities in all aspects of standards-based reform-setting standards, participating in assessments, making assessment accommodations, reporting results, developing accountability systems, and teaching/learning. Much of the information that I cite is based on investigations and analyses conducted by the National Center on Educational Outcomes (NCEO), a federally funded center that has followed these issues for 10 years. I conclude by highlighting what I believe to be some of the lessons we have learned about including students with disabilities in standards-based reform.

\section{A BRIEF HISTORY OF STANDARDS AND STANDARDS-BASED REFORM}

Content standards define what students should know and be able to do (i.e., knowledge and skills) as a result of their schooling and other educational experiences. Performance standards define how well students must perform to demonstrate adequate knowledge and skills-"how good is good enough?" Together, content and performance standards have formed the kernal of standards-based reform in the United States in the past decade.

Martha L. Thurlow is Director of the National Center on Educational Outcomes at the University of Minnesota.

(c) Love Publishing Company. 2000 
States started defining content standards in the early 1990 s, often spurred by work on national standards (e.g., National Council of Teachers of Mathematics, 1989; National Research Council, 1993) or by the 1989 educational summit at which the national educational goals were first identified (see National Council on Education Standards and Testing, 1992). Various groups and news media began to rate standards (e.g., American Federation of Teachers, 1999; Fordham Foundation, 2000; State Policy Updates, 2000), further elevating their importance in the eyes of the public.

Federal laws also were written to promote the development and implementation of standards and educational reforms based on them. Table 1 summarizes three of the most important of these laws: Goals 2000, Title I of the Improving America's Schools Act, and the Individuals with Disabilities Education Act. These federal laws have helped to solidify the importance assigned to standards and the standards-based reform movement, as well as to highlight the notion that standards and reforms are meant for all students, including students with disabilities.

Standards-based reforms, however, have involved more than just setting standards. Hand-in-hand with them have

\section{FOcuson
Exceptional
childiren}

ISSN $0015-511 \mathrm{X}$

FOCUS ON EXCEPTIONAL CHILDREN (USPS 203-360) is published monthly except June, July, and August as a service to teachers. special educators, curriculum specialists, administrators, and those concerned with the special education of exceptional children. This publication is annotated and indexed by the ERIC Clearinghouse on Handicapped and Gifted children for publication in the monthly Current Index to Joumals in Education (CIJE) and the quarterly index, Exceptional Children Education Resources (ECER). The full text of Focus on Exceptional Children is also available in the electronic versions of the Education Index. It is also available in microfilm from Xerox University Microfilms, Ann Arbor, MI. Subscription rates: Individual, $\$ 30$ per year: institutions, $\$ 40$ per year. Copyright (c) 2000, Love Publishing Company. All rights reserved. Reproduction in whole or part without written permission is prohibited. Printed in the United States of America. Periodicals postage is paid at Denver, Colorado. POSTMASTER: Send address changes to:

$$
\begin{gathered}
\text { Love Publishing Company } \\
\text { Executive and Editorial Office } \\
\text { P.O. Box } 22353 \\
\text { Denver. Colorado } 80222 \\
\text { Telephone (303) } 221-7333
\end{gathered}
$$

$$
\text { Karen Harris }
$$

University of Maryland

James Shriner

University of Illinois
Thomas Skrtic University of Kansas

Stanley F. Love Publisher come state and district assessments, reporting systems, and accountability mechanisms. Today, all except two states have state-level assessments. District-level assessments exist in the majority of districts spread throughout the states. High-stakes assessments that have significant consequences for districts, schools, administrators, educators, or the students themselves have mushroomed in an attempt to improve the performance of students (Education Commission of the States, 1999).

By the end of the century, 40 of the states had implemented (or were in the process of implementing) assessments that resulted in significant consequences (rewards or sanctions) for schools or the educators within them. More than 20 states had implemented (or were in the process of implementing) assessments that resulted in significant consequences for students (high school diplomas, promotion from one grade to the next). Assessment has become big business, a business that now is addressing how to include students with disabilities (and other formerly excluded students, such as students with limited English proficiency).

\section{INCLUDING STUDENTS WITH DISABILITIES IN STANDARDS-BASED REFORM}

The finding that students with disabilities were being excluded from national and state assessments (Ingels, 1993, 1996; Ingels \& Scott, 1993; McGrew, Thurlow, Shriner, \& Spiegel, 1992) was one of the first indicators that students with disabilities might not receive the benefits associated with standards-based reforms. Evidence of this exclusion came from parents and students themselves, who indicated that students were purposely being excluded (e.g., Why Johnny stayed home, 1997), as well as from surveys of states and attempts to collect data from national and state assessment data bases (McGrew, Algozzine, Ysseldyke, Thurlow, \& Spiegel, 1995; McGrew, Vanderwood, Thurlow, \& Ysseldyke, 1995), as well as from school districts (Zlatos, 1992). Inquiry into the exclusion of students with disabilities revealed that the problem existed at several points, each of which was a point of possible change.

\section{Setting Standards}

Probably the first point of exclusion occurred when standards were being developed. Initially, evidence of exclusion was found in the national standards under development by various national associations (Hofmeister, 1993; Shriner, Kim, Thurlow, \& Ysseldyke, 1992; Ysseldyke, Thurlow, \& Shriner, 1992). As states began to develop their own standards, analyses of them suggested that students with disabilities had not been considered (Thurlow, Ysseldyke, Gutman, \& Geenen, 1998). This conclusion was supported by the findings that (a) only $17 \%$ of the states with standards (47 at 
TABLE 1.

Key Standards Provisions in Goals 2000, IASA (Title I), and IDEA

\begin{tabular}{|c|c|c|}
\hline Federal Law & Year Enacted & Standards-related Provisions \\
\hline \multirow[t]{2}{*}{$\begin{array}{l}\text { Goals 2000: } \\
\text { Educate America Act }\end{array}$} & 1994 & $\begin{array}{l}\text { "It is the purpose of this part to establish a bipartisan mechanism } \\
\text { for - . . reviewing the voluntary national content standards, volun- } \\
\text { tary national student performance standards, and voluntary national } \\
\text { opportunity to learn standards certified by the National Education } \\
\text { Standards and Improvement Council..." [Sec. } 201 \text { (3)] }\end{array}$ \\
\hline & & $\begin{array}{l}\text { "It is the purpose of this part to establish a mechanism to - (1) cer- } \\
\text { tify and periodically review voluntary national content standards and } \\
\text { voluntary national student performance standards that define what all } \\
\text { students should know and be able to do; (2) certify state content } \\
\text { standards and State student performance standards submitted by } \\
\text { States on a voluntary basis, if such standards are comparable or } \\
\text { higher in rigor and quality to the voluntary national content standards } \\
\text { and voluntary national student performance standards certified by the } \\
\text { National Education Standards and Improvement Council." [Sec. } 211 \text {. } \\
\text { (1) (2)] }\end{array}$ \\
\hline \multirow[t]{3}{*}{$\begin{array}{l}\text { Improving America's } \\
\text { Schools Act (Title I) }\end{array}$} & 1994 & $\begin{array}{l}\text { "[Title I] programs need to become even more effective in improving } \\
\text { schools in order to enable all children to achieve high standards; and } \\
\text { in order for all students to master challenging standards in core acad- } \\
\text { emic subjects." [Sec. } 1001 \text { (b) (4) (5)] }\end{array}$ \\
\hline & & $\begin{array}{l}\text { "If a state has not adopted State content standards and State student } \\
\text { performance standards for all students, the State plan shall include a } \\
\text { strategy and schedule for developing State content standards and } \\
\text { State student performance standards for elementary and secondary } \\
\text { school children served under this part in subjects as determined by } \\
\text { the State, but including at least mathematics and reading or language } \\
\text { arts by the end of the one-year period...." [Sec. } 1111 \text { (b) (1) (C)] }\end{array}$ \\
\hline & & $\begin{array}{l}\text { "State rules, regulations, and policies under this title shall support } \\
\text { and facilitate local educational agency and school-level systemic } \\
\text { reform designed to enable all children to meet the challenging State } \\
\text { content standards and challenging State student performance stan- } \\
\text { dards." [Sec } 1603 \text { (a) (2)] }\end{array}$ \\
\hline \multirow[t]{3}{*}{$\begin{array}{l}\text { Individuals with } \\
\text { Disabilities Education } \\
\text { Act (IDEA) }\end{array}$} & 1997 & $\begin{array}{l}\text { "All educational programs for children with disabilities in the State, } \\
\text { including all such programs administered by any other State or local } \\
\text { agency -... meet the educational standards of the State education } \\
\text { agency...." [Sec. } 612 \text { (a) (11) (A) (ii) II] }\end{array}$ \\
\hline & & $\begin{array}{l}\text { "PERFORMANCE GOALS AND INDICATORS }-\ldots \text { are consistent, } \\
\text { to the maximum extent appropriate, with other goals and standards } \\
\text { for children established by the State...." [Sec. } 612 \text { (a) (16) (A) (ii)] }\end{array}$ \\
\hline & & $\begin{array}{l}\text { "The Federal Government has an ongoing obligation to support pro- } \\
\text { grams, projects, and activities that contribute to positive results for } \\
\text { children with disabilities, enabling them to meet their early interven- } \\
\text { tion, educational, and transitional goals and, to the maximum extent } \\
\text { possible, educational standards that have been established for all } \\
\text { children." [Sec } 671 \text { (a) (1) (A)] }\end{array}$ \\
\hline
\end{tabular}


the time of the analysis) had included individuals with disabilities (or those who were familiar with them) in developing their standards, and (b) $23.4 \%$ did not mention students with disabilities in any of their core subject area documents.

As part of the Improving America's School Act (IASA), Title I provisions, states must have standards in math and English/Language Arts, at minimum. And, when measuring adequate yearly progress, the performance of all students against these standards must be measured (U.S. Department of Education, 1999). Thus, standards (content and performance) must apply to all students (Thurlow \& Ysseldyke, 2000) and, more important, these standards should be tied to effective assessments (Business Roundtable, 1996).

\section{Participating in Assessments}

Assessment is the mechanism by which states are measuring whether students are meeting standards. Yet, for nearly half of the past decade, students with disabilities were excluded from assessments not just during the time when assessments were administered but also when the items were developed and when results were tabulated and reported. In the early 1990 s (Shriner \& Thurlow, 1992), the rate of participation of students with disabilities in assessments ranged from $0 \%$ to $100 \%$. Within a few years of this finding, it became evident that many states and districts did not really know how many students with disabilities had participated in assessments because their data management systems were not designed to address the participation of students with disabilities or they had not figured out how to keep track of whether these students had actually taken the test (Erickson, Thurlow, \& Ysseldyke, 1996; Erickson, Ysseldyke, \& Thurlow, 1997).

Excluding students with disabilities during administration of the test generally decreased over time, even as states began to have better estimates of participation rates. In the early 1990s, most states had $10 \%$ or fewer of their students with disabilities in assessments (Shriner \& Thurlow, 1992). By the mid-1990s, this had changed somewhat. More states indicated that they knew how many students participated in assessments, and the number of states indicating that fewer than $10 \%$ of their students with disabilities were included in assessments decreased (Elliott, Erickson, Thurlow, \& Shriner, 2000).

The reauthorization of IDEA in 1997 escalated these changes because it required that states include students with disabilities in their state and districtwide assessments and report on their findings by July 1, 1998 (see Table 2 for large-scale assessment requirements of Title I and IDEA). In 1999 , estimates of participation rates by states were still variable, ranging from $15 \%$ to $100 \%$ (Thompson \& Thurlow, 1999), but most states now had estimates of about
$60 \%-65 \%$ of their students with disabilities participating in the statewide assessment.

Another indicator of participation that has changed over time is the written policies that states have about the participation of students with disabilities in the general state assessment. In the early $1990 \mathrm{~s}$, written-participation policies existed in fewer than half of the states (Thurlow, Ysseldyke, \& Silverstein, 1993) and often indicated that students with disabilities need not take the general assessment. By the mid-1990s, 43 states had written participation policies, more of them indicating an intent to include students with disabilities in assessments (Thurlow, Scott, \& Ysseldyke, 1995b). And, by the end of the century, all states with active assessment systems have written policies about participation in assessments (Thurlow, House, Boys, Scott, \& Ysseldyke, 2000).

IDEA also required that states begin the development and implementation of alternate assessments, to be used with students unable to participate in the general state assessment. This would mean that every student with a disability would be included in some type of state or districtwide assessment. The first known alternate assessment was developed in Kentucky, in response to the Kentucky Educational Reform Act (KERA) (Ysseldyke, Thurlow, Erickson, Gabrys, et al., 1996). In Kentucky, the alternate assessment is a portfolio system, designed to be consistent with portfolio assessments used with other students.

As states neared the time when they were to have alternate assessments in place, most states had developed something (Thompson \& Thurlow, 2000). As might be expected, however, states were at a variety of stages in their development process. Similarly, they had taken many different approaches in their alternate assessments (see Figure 1). This might be expected, since their general assessments were also quite varied in purpose and characteristics (Olson, Bond, \& Andrews, 1999).

With the development of alternate assessments, it would be expected that all students with disabilities now will be included in each state's assessment system. The same should be true for district-wide assessments, although the extent to which this has happened is still unclear. The expectation that all students would be included in state and district assessments was made clear in an answer about alternate assessments given in a question-and-answer memo prepared for states by the Office of Special Education Programs (Heumann \& Warlick, 2000):

12. Do the requirements to establish participation guidelines for alternate assessments and to develop alternate assessments apply to both SEAs and LEAs?

Yes. 34 CFR $\$ 300.138$ specifically requires inclusion of children with disabilities in both State and district-wide assessment programs and requires both the SEA and the 
TABLE 2.

Key Assessment Provisions in IASA (Title I), and IDEA

\begin{tabular}{|c|c|c|}
\hline Federal Law & Year Enacted & Assessment-Related Provisions \\
\hline \multirow[t]{3}{*}{$\begin{array}{l}\text { Improving America's } \\
\text { Schools Act (Title I) }\end{array}$} & \multirow[t]{3}{*}{1994} & $\begin{array}{l}\text { “... high-quality, yearly student assessments ... that will be used } \\
\text { as the primary means of determining the yearly performance of each } \\
\text { local educational agency and school served under this part in } \\
\text { enabling all children served under this part to meet the State's stu- } \\
\text { dent performance standards. (A) Such assessments shall be the same } \\
\text { assessments used to measure the performance of all children, if the } \\
\text { State measures the performance of all children (F)... provide for } \\
\text { the participation in such assessments of all students (i)." [Sec. } 1111 \\
\text { (b) (3) (A) (F) (i)] }\end{array}$ \\
\hline & & $\begin{array}{l}\text { "A State educational agency shall }-\ldots \text { publicize and disseminate to } \\
\text { local educational agencies, teachers and other staff, parents, students, } \\
\text { and the community the results of the State review, including statisti- } \\
\text { cally sound results, as required by section } 1111 \text { (b) (3) (1)." [Sec. } 116 \\
\text { (d) (1) (B)] }\end{array}$ \\
\hline & & $\begin{array}{l}\text { “... enable results to be disaggregated with each State, local educa- } \\
\text { tional agency, and school by ... students with disabilities as com- } \\
\text { pared to nondisabled students...." [Sec. } 1111 \text { (b) (3) (I)] }\end{array}$ \\
\hline \multirow[t]{4}{*}{$\begin{array}{l}\text { Individuals with } \\
\text { Disabilities Education } \\
\text { Act (IDEA) }\end{array}$} & \multirow[t]{4}{*}{1997} & $\begin{array}{l}\text { "Children with disabilities are included in general State and } \\
\text { district-wide assessment programs, with appropriate accommodations, } \\
\text { where necessary." [Sec. } 612 \text { (a) (17) (A)] }\end{array}$ \\
\hline & & $\begin{array}{l}\text { "As appropriate, the State or local educational agency develops } \\
\text { guidelines for the participation of children with disabilities in alter- } \\
\text { nate assessments for those children who cannot participate in State } \\
\text { and district-wide assessment programs." [Sec. } 612 \text { (a) (18) (A) (i)] }\end{array}$ \\
\hline & & $\begin{array}{l}\text { "The national assessments shall examine how well schools, local } \\
\text { educational agencies, States and other recipients of assistance under } \\
\text { this Act ... including improving the performance of all children with } \\
\text { disabilities in general scholastic activities and assessments as com- } \\
\text { pared to nondisabled children; providing for the participation of chil- } \\
\text { dren with disabilities in the general curriculum." [Sec. } 673 \text { (b) (3) } \\
\text { (A) (B)] }\end{array}$ \\
\hline & & $\begin{array}{l}\text { "The State educational agency makes available to the public, and } \\
\text { reports to the public with the same frequency and in the same detail } \\
\text { as it reports on the assessment of nondisabled children, the follow- } \\
\text { ing: the number of children with disabilities participating in regular } \\
\text { assessments. The number of those children participating in alternate } \\
\text { assessments. The performance of those children on regular assess- } \\
\text { ments (beginning not later than July } 1,1998 \text { ) and on alternate assess- } \\
\text { ments (not later than July } 1,2000 \text { ), if doing so would be statistically } \\
\text { sound and would not result in the disclosure of performance results } \\
\text { identifiable to individual children." [Sec. } 612 \text { (a) (17) (B) (i) (ii) (iii) } \\
\text { (I) (II)] }\end{array}$ \\
\hline
\end{tabular}




\begin{abstract}
LEA. as appropriate, to develop guidelines for the participation of children with disabilities in alternate assessments for those children who cannot participate in State and districtwide assessments, and develop alternate assessments.

Of course. if an LEA does not conduct district-wide assessments other than those that are part of the State assessment program, then the LEA would follow SEA guidelines and use the SEA alternate assessment( $(S)$. The requirements apply to district-wide assessments regardless of whether or not there is a State assessment. (Heumann \& Warlick, 2000, p. 10)
\end{abstract}

\section{Assessment Accommodations}

Participation of students with disabilities in general state and district-wide assessments is intimately linked to the availability of accommodations for students with disabilities. Accommodations are "changes in testing materials or procedures that enable students with disabilities to participate in an assessment in a way that allows abilities to be assessed rather than disabilities" (Thurlow, Elliott, \& Ysseldyke, 1998, pp. 28-29). More specifically, accommodations generally are considered to include changes in presentation, response, timing, scheduling, setting, and other aspects of the testing situation. A few examples of each of these are shown in Table 3 .

For some time, researchers and others suspected that by allowing accommodations (or more accommodations than before), the participation rates of students with disabilities in assessments probably would increase (Thurlow, Elliott, \& Ysseldyke, 1998; Ysseldyke, Thurlow, McGrew, \& Shriner,
1994; Ysseldyke, Thurlow, McGrew, \& Vanderwood, 1994). A study commissioned by the National Center for Education Statistics (Anderson, Jenkins, \& Miller, 1996) showed empirically that this was true. A special study using the National Assessment of Educational Progress (NAEP), which is used as a report card for the country, evaluated whether participation rates would increase with the availability of accommodations. Reporting on the findings of that study, Mazzeo, Carlson, Voekl, and Lutkus (2000) noted that the participation rates did not increase as a result of changing inclusion criteria, but did increase when some accommodations were available during testing.

Although convincing evidence now exists that providing accommodations increases the participation of students with disabilities, accommodations remain controversial. This is a result, in part, of concerns that accommodations provide students who use them with an advantage that other students do not have. It also is related to some specific accommodations linked to the constructs being assessed (e.g., reading to the student a test of decoding skills), and therefore may produce invalid or noncomparable scores (e.g., Koretz, 1997).

Despite these concerns, state policies on accommodations have changed dramatically. In 1991, when NCEO first requested information from states about accommodations, fewer than half the states had written policies or guidelines (Shriner \& Thurlow, 1992). In 1993, 21 states had written guidelines (Thurlow, Ysseldyke, \& Silverstein, 1993), and by 1995,38 states had them (Thurlow, Scott, \& Ysseldyke,

TABLE 3.

Examples of Accommodations

Setting
Study carrel
Special lighting
Separate room
Individualized or small group administration

Timing

Extended time

Frequent breaks

Unlimited time

\section{Presentation}

Repeat directions

Larger bubbles on multiple-choice questions

Sign language presentation

Magnification device

\section{Scheduling}

Specific time of day

Subtests in different order

\section{Response}

Mark answers in test booklet

Use reference materials (e.g., dictionary)

Word process writing sample

\section{Other}

Special test preparation techniques Out-of-level test 
1995a). By 1999, all states with state-level assessments had written policies or guidelines about the use of accommodations during state assessments (Thurlow, House, Boys, Scott, \& Ysseldyke, 2000).

Although information about allowed accommodations existed (see also Olson et al., 1999), this information did not reflect the extent to which students with disabilities were using accommodations. NCEO had encouraged states to collect data on the use of accommodations, and by the end of the decade, several states had these data (Elliott, Bielinski, Thurlow, DeVito, \& Hedlund, 1999; Thompson \& Thurlow, 1999; Trimble, 1998). The data were very revealing (see Table 4 ) because variability in the use of accommodations was so great from state to state. In one state the use of accommodations at a particular grade level was less than $8 \%$ of the students; in another state the use of accommodations at a particular grade level was more than $80 \%$ of the students (Thompson \& Thurlow, 1999). These data hint at the confusion surrounding the term "accommodation," the way in which accommodations are counted, and differences in beliefs about the appropriateness of using accommodations.

\section{Confusion About What an "Accommodation" Is}

Terminology has plagued our understanding of accommodations. First, different terms are sometimes used to mean the same thing. Thus, in some states acceptable testing changes are called accommodations, in others they are called modifications, and in others they are called adaptations. Second, the same term may be used to mean different things. For example, in some states and districts the term "modification" refers to an acceptable change in the test itself, such as a braille or large-print version. In other states and districts the term "modification" is used to mean a change that is not acceptable-a change that may compromise the construct being assessed (such as reading a test to a student that is designed to assess reading decoding skills).

\section{Confusion About Which Accommodations To Count}

Given the variability in terminology, it should be apparent that states and districts think about different accommodations in different ways. For example, if State A counts using a pencil holder or a slantboard on the desk as an accommodation, but State $B$ does not, there will certainly be a difference in the number of students counted as using accommodations, and in the number of accommodations used during a test. This scenario reflects the current status of states that are tracking the use of accommodations. Some states are counting only those changes in testing about which they have concerns. Other states are counting all changes in the testing, regardless of whether they were considered to be perfectly acceptable or ones that challenged the meaningfulness of scores obtained when they were used.

\section{Differences in Beliefs About the Appropriateness of Accommodations}

Remaining at the core of confusion about how accommodations interact with the participation of students who have disabilities in assessments is an array of beliefs about the acceptability of either specific accommodations or accommodations in general. Clear evidence of these differences exists in the written policies and guidelines that states have developed. Although all states with assessments now have written information about which accommodations are allowed, the specific accommodations allowed and not allowed vary tremendously.

The variation extends beyond that expected from the different tests that states use. Even in states using the same test, accommodations on the allowed and not-allowed lists are different (Thurlow, House, Boys, Scott, \& Ysseldyke, 2000). This indicates, in part, that the policies are not based on research findings about the appropriateness of specific accommodations.

In fact, test developers are just beginning to address accommodations issues (e.g., CTB McGraw-Hill, 2000), For many years, information on the accommodations that students could use when taking the major achievement tests used by districts and states (e.g., California Achievement Test, Iowa Test of Basic Skills, Metropolitan Achievement Test, Stanford Achievement Test) was either nonexistent or very limited (see summary in Thurlow, Elliott, \& Ysseldyke 1998). Today, a host of research efforts is underway to address the effects of specific accommodations on score comparability, as well as the decision-making process to identify specific accommodations needed by individual students. Many of these efforts are funded either by the Office of Special Education Programs (OSEP) or the Office of Educational Research and Improvement (OERI). In addition, several additional research efforts are emerging, often supported by states as they struggle with their own policies on accommodations

\section{Reporting of Assessment Results}

Simply having students with disabilities take tests, with the accommodatons they need, is not enough to provide students with the benefits to be derived from standards-based reform. The importance of reporting the performance results of students with disabilities emerged as another critical aspect of including students with disabilities in standardsbased reforms (Erickson, Ysseldyke, Thurlow, \& Elliott, 1997). Although changes in individual programs may result from providing large-scale assessment information to teachers and parents, public reporting is what prompts programmatic improvements (Elmore \& Rothman, 1999).

The first effort to determine the extent to which states reported on the performance of students with disabilities 
TABLE 4.

State-reported Levels of Use of Accommodations

\begin{tabular}{|c|c|c|c|c|}
\hline State & $\begin{array}{l}\text { Assessment/ } \\
\text { Subject Area }\end{array}$ & $\begin{array}{l}\text { Elementary } \\
\text { Grades (K-5) }\end{array}$ & $\begin{array}{l}\text { Middle School } \\
\text { Grades }(6-8)\end{array}$ & $\begin{array}{l}\text { High School } \\
\text { Grades }(9-12)\end{array}$ \\
\hline Florida & $\begin{array}{l}\text { FL Writing Assessment } \\
\text { FCAT (Reading) } \\
\text { FCAT (Math) }\end{array}$ & $\begin{array}{l}51 \%(\mathrm{Gr} 4) \\
47 \%(\mathrm{Gr} 4) \\
50 \%(\mathrm{Gr} 5)\end{array}$ & $\begin{array}{l}39 \%(\mathrm{Gr} 8) \\
38 \%(\mathrm{Gr} 8) \\
38 \%(\mathrm{Gr} 8)\end{array}$ & $\begin{array}{l}34 \%(\text { Gr } 10) \\
40 \%(\text { Gr } 10) \\
39 \%(\text { Gr } 10)\end{array}$ \\
\hline Indiana & $\begin{array}{l}\text { Statewide Assessment - Math } \\
\text { English/Language Arts }\end{array}$ & $\begin{array}{l}28 \%(\mathrm{Gr} 3) \\
29 \%(\mathrm{Gr} 3)\end{array}$ & $\begin{array}{l}34 \%(\mathrm{Gr} 6) \\
38 \%(\mathrm{Gr} 8) \\
34 \%(\mathrm{Gr} 6) \\
38 \%(\mathrm{Gr} 8)\end{array}$ & $\begin{array}{l}80 \%(\mathrm{Gr} 10) \\
82 \%(\mathrm{Gr} 10)\end{array}$ \\
\hline Kansas & $\begin{array}{l}\text { KS Assessment Program - Math } \\
\text { Reading } \\
\text { Writing }\end{array}$ & $\begin{array}{l}21 \%(\text { Gr } 4) \\
19 \%(\text { Gr } 3) \\
23 \%(\text { Gr } 5)\end{array}$ & $\begin{array}{l}14 \%(\mathrm{Gr} 7) \\
13 \%(\mathrm{Gr} 7) \\
17 \%(\mathrm{Gr} 7)\end{array}$ & $\begin{array}{l}08 \%(\text { Gr } 10) \\
08 \%(\text { Gr } 10) \\
09 \%(\text { Gr } 10)\end{array}$ \\
\hline Kentucky & Kentucky Core Content Test & $\begin{array}{l}82 \%(\text { Gr } 4) \\
82 \%(\text { Gr } 5)\end{array}$ & $\begin{array}{l}72 \%(\text { Gr } 7) \\
70 \%(\text { Gr } 8)\end{array}$ & $\begin{array}{l}50 \%(\mathrm{Gr} 10) \\
57 \%(\mathrm{Gr} 11) \\
55 \%(\mathrm{Gr} 12)\end{array}$ \\
\hline Massachusetts & Comprehensive Assessment System & $61 \%(\mathrm{Gr} 4)$ & $38 \%(\mathrm{Gr} 8)$ & $25 \%(\mathrm{Gr} 10)$ \\
\hline Maryland & $\begin{array}{l}\text { MSPAP-Reading } \\
\text { Language Usage } \\
\text { Math }\end{array}$ & $\begin{array}{l}53 \%(\text { Gr } 3) \\
51 \%(\text { Gr } 5) \\
44 \%(\text { Gr } 3) \\
41 \%(\text { Gr } 5) \\
20 \%(\text { Gr } 3)\end{array}$ & $\begin{array}{l}25 \%(\mathrm{Gr} 8) \\
16 \%(\mathrm{Gr} 8)\end{array}$ & \\
\hline Nevada & Terra Nova Complete Battery & $51 \%(\mathrm{Gr} 4)$ & $42 \%(\mathrm{Gr} 8)$ & $44 \%(\mathrm{Gr} 10)$ \\
\hline New York & $\begin{array}{l}\text { PEP Test-Reading } \\
\text { Math } \\
\text { Writing }\end{array}$ & $\begin{array}{l}50 \%(\text { Gr } 3) \\
31 \%(\text { Gr } 3) \\
33 \%(\text { Gr } 5)\end{array}$ & $\begin{array}{l}50 \%(\mathrm{Gr} 6) \\
32 \%(\mathrm{Gr} 6)\end{array}$ & \\
\hline Pennsylvania & Reading and Math Assessment & $67 \%(\mathrm{Gr} 5)$ & $52 \%(\mathrm{Gr} 8)$ & $45 \%(\mathrm{Gr} 11)$ \\
\hline Rhode Island & $\begin{array}{l}\text { Writing Performance Assessment } \\
\text { Health Performance Assessment }\end{array}$ & $\begin{array}{l}49 \%(\mathrm{Gr} 3) \\
39 \%(\mathrm{Gr} 5)\end{array}$ & $\begin{array}{l}55 \%(\text { Gr } 7) \\
61 \%(\text { Gr } 9)\end{array}$ & $60 \%(\mathrm{Gr} 10)$ \\
\hline South Dakota & $\begin{array}{l}\text { Stanford Achievement Test } \\
\text { (Language, Math, Reading, Science, } \\
\text { Social Science) }\end{array}$ & $\begin{array}{l}63 \%(\mathrm{Gr} 2) \\
67 \%(\mathrm{Gr} 4)\end{array}$ & $59 \%(\mathrm{Gr} 8)$ & $46 \%($ Gr 11$)$ \\
\hline West Virginia & $\begin{array}{l}\text { SAT 9-Language, Math, Reading, } \\
\text { Science, Social Studies }\end{array}$ & $64 \%(\mathrm{Gr} 3-11)$ & & \\
\hline
\end{tabular}


occurred just before the amendments to IDEA were enacted (Thurlow, Langenfeld, Nelson, Shin, \& Coleman, 1998). The amendments required states to publicly report on the performance of students with disabilities in the same way and with the same frequency as they reported on the performance on other students.

This analysis, based on 1996 state reports, indicated that only 11 states provided test-based data on students with disabilities. Five of these states reported on the performance of students with disabilities in documents separate from those in which data on other students were presented.

Follow-up analyses, using state reports from 1998 (Ysseldyke, et al., 1998) and 1999 (Thurlow, Nelson, Teelucksingh, \& Ysseldyke, 2000) showed meager increases-12 states in 1998 reports and 17 states in 1999 reports. The number of states publicly reporting will certainly increase in the next couple years, as data management, policy, and other issues are slowly resolved.

These data are important for a number of reasons, other than the importance of knowing how students with disabilities across the nation are performing. Besides confirming that, in general, students with disabilities are performing below their peers, the data open up avenues to exploring changes over time. Two such analyses have revealed important increases in the performance of students with disabilities over time in standards-based educational systems (Keller, 2000; Trimble, 1998). Other analyses have helped to identify how states can get better information when looking at trends in performance (Bielinski \& Ysseldyke, 2000).

\section{Accountability Systems}

Accountability is one facet of standards-based reform that generates considerable emotion and controversy. Accountability systems can be focused either on the student (such as graduation exams and tests used to decide on promotion from one grade to another) or on the system (such as when schools are taken over, when staff members receive rewards, or when accreditation in based on student performance). State accountability systems vary in their approaches and in the consequences tied to them (Education Commission of the States, 1999).

\section{Student Accountability}

Holding the student responsible for his or her performance on state and district tests is increasing in popularity among governors and legislators. At the same time, concern about including students with disabilities in assessments is heightened because of these kinds of assessments (Thurlow, in press; Thurlow \& Johnson, 2000). There is concern about large numbers of students with disabilities not passing these tests, and thereby being relegated to a pathway that is sure to lead to dropping out of school or eventually having poor prospects for employment and post-secondary training (Thurlow \& Johnson, 2000). Despite numerous warnings that systems should be held accountable for student learning and have their systems in place for ensuring equal opportunity to learn to all students (Heubert \& Hauser, 1999), this has not stopped the proliferation of these tests (see American Federation of Teachers, 1999; Guy, Shin, Lee, \& Thurlow, 1999).

Guy et al. (1999) explored states' graduation requirements and found a confusing array of requirements designed specifically for students with disabilities, even in states using graduation exams. This confusion is exemplified not only in variations in course requirements and testing requirements for students with disabilities - in some states but not in others-but also in an array of diploma options, from IEP diplomas, special education diplomas, and modified diplomas to the same diploma but different documentation on transcripts.

In an NCEO report (Thurlow \& Thompson, 2000), we highlighted these variations and related some thoughts about how all students can have access to the same array of diploma options (see Table 4). Unfortunately, this does not represent what is happening in most states.

High stakes exams that punish or reward students are going to continue to be a controversial topic until it is clear that all students have equal opportunity to learn. Court cases are addressing these issues now with increasing frequency (e.g., Olson, 2000), and the number of cases of this nature probably will continue to increase until some of the issues surrounding appropriate opportunity to learn for all students are adequately addressed.

\section{Systems Accountability}

When consequences are significant, complex formulas often are used to determine how accountability scores are calculated for schools and districts. Yet, these formula are not accessible to the public (Krentz, Thurlow, \& Callender, 2000). Further, finding out how students with disabilities are included (or not) in these formula was nearly impossible. Some states do have clear information, often because their state legislatures have required it. The goal of the Improving America's School Act, of course, is that all students are to be included in the accountability system.

Because students with disabilities now are included in the assessments that form the basis of most accountability systems, we should expect to begin to see clear evidence of their inclusion in this component of standards-based reform. Through their inclusion in the accountability system, states and districts will begin to see the importance of ensuring that their instructional programs and placements are the best they can be. 


\section{Teaching and Learning}

When the discussion turns to assessments and accountability systems, perhaps the most important elements of standardsbased reform-teaching and learning - are often forgotten. It is important to remember that the impetus for standards-based reform was the desire to improve teaching and learning so all students could demonstrate the knowledge and skills needed in the global economy of today and the future.

With the emphasis given to assessments as the measures of whether students were achieving standards, several unintended consequences of standards-based reforms began to emerge. One was the tendency for the curriculum to narrowto focus only on the knowledge and skills included in assessments (Heubert \& Hauser, 1999; Linn, 2000; Linn \& Herman, 1997; Shepard, 1991). Although some states argued that narrowing of the curriculum was appropriate if the test was measuring the appropriate standards, there continues to be concern about teaching to the test, and teaching students only how to take tests better - not to gain a broad knowledge base and set of skills that will be reflected in higher test performance (Heubert \& Hauser, 1999; Kohn, 2000; Shepard, 1991).

Beyond this, when looking at state standards, it soon became apparent that not all standards were the same. Some states had relatively broad standards such as, "Students compare patterns of change and constancy in systems," whereas others had quite narrow standards such as, "Students describe the basic processes of photosynthesis and respiration and their importance to life" (examples from states cited in American Federation of Teachers, 1996). The extent to which standards are broad or narrow affects the nature of the curriculum for students with disabilities, particularly those who may be determined to be eligible to participate in the assessment system through the alternate assessment.

Discussions about how broad or narrow standards are is particularly relevant when considering the curriculum for students with disabilities. In the early 1990s the National Center on Education Outcomes devoted considerable time, and involved hundreds of stakeholders, in efforts to identify the important outcomes of education for students with disabilities (Ysseldyke, Thurlow, \& Gilman, 1993a, 1993b, 1993c, 1993d; Ysseldyke, Thurlow, \& Erickson, 1994a, 1994b). The outcome models that were developed were for all students, since the broad group of stakeholders kept all students in mind as the outcomes were developed. They reflected broad domains, including Presence \& Participation, Accommodation and Adaptation, Physical Health, Social/Emotional Adjustment, Independence \& Responsibility, Contribution \& Citizenship, and Satisfaction, as well as Academic \& Functional Literacy (see also Ysseldyke, Krentz, Elliott, Thurlow, Erickson, \& Moore, 1998).
Regardless of what kinds of standards the states developed, however, state assessments tended to focus on material that was easy to test. The tendency not to use performance assessments, but instead to consider extended response items to be a proxy for performance assessments, turned around the discussion once again to concerns about the nature of the curriculum that might be directed only to doing well on a test.

Although this concern about narrowing of the curriculum permeated education, its effects might be most devastating for students with disabilities, particularly those who might not be headed for college. Would students who were not eligible for the alternate assessment be short-changed because their curriculum focused only on academics, with little concern about ensuring that they were learning broader skills or being prepared for transition into the world of work? These were legitimate concerns as the focus on standards-based education continued into the new century.

Elliott and Thurlow (2000) identified several characteristics of a standards-based classroom:

\footnotetext{
"Students know the standards and level of proficiency required," (b) Students are provided multiple opportunities to learn," (c) Student assignments reflect an integration of facts, concepts, and strategies," and (d) "Each assignment is an assessment in itself." (pp. 42-43)
}

They suggest that IEPs must be linked to standards-a concept that aligns with access to the general education curriculum-and that standards must be backmapped to instruction. Nowhere is there the implication that the purpose is to narrow the curriculum or teach to the test. In fact, time and again, researchers have verified the importance of teaching broadly, using the best instructional procedures available.

The themes about the importance of the instructional process and an appropriate, standards-based curriculum were echoed by the National Research Council's report (Elmore \& Rothman, 1999), Testing, Teaching and Learning: A Guide for States and School Districts. The importance of "authentic pedagogy" (see Newmann \& Associates, 1996) for all students was highlighted. The instruction involves higher-order thinking, deep knowledge, substantive conversation, and connections to the world beyond the classroom. Classroom studies find that these qualities are rarely present (David, 1997; Spillane, 1997).

The National Research Council report presented five recommendations for ways to ensure that instruction is appropriate for standards-based learning (Elmore \& Rothman, 1999):

- Schools and districts should monitor the conditions of instruction--the curriculum and instructional practices of teachers-to determine if students are exposed 
to teaching that would enable them to achieve the standards they are expected to meet.

- Districts and schools should use information on the conditions of instruction to require and support improvement of instruction and learning in every classroom.

- Teachers should use the information on conditions of instruction in their classroom, along with data on student performance, to improve the quality of instruction. Districts have a responsibility to assist schools in collecting and using such information.

- Schools should use the information on the conditions of instruction to organize the time and resources provided to teachers and demand support from the district.

- Districts should use the information on the conditions of instruction to improve the quality and effectiveness of the resources and support they provide to schools for instructional improvement. (p. 77)

With evidence that students who are lower-performing are least likely to get equal access to a standards-based curriculum, and are more likely to receive poorer instruction (Bradley, 2000; National Association of State Boards of Education, 1998; U.S. Department of Education, 1995), curriculum and instructional issues are likely to remain among the most important for students with disabilities as the move into standards-based education continues.

\section{LESSONS LEARNED ABOUT INCLUDING STUDENTS WITH DISABILITIES IN STANDARDS-BASED REFORMS}

Just prior to passage of the reauthorization of the Individuals with Disabilities Education Act in 1997, the National Research Council conducted a study of students with disabilities and standards-based reform (McDonnell, McLaughlin, \& Morison, 1997). One product of this effort was the development of a set of recommendations as follows:

Recommendation 1. States and localities that decide to implement standards-based reforms should design their common content standards, performance standards, and assessments to maximize participation of students with disabilities.

Recommendation 2. The presumption should be that each student with a disability will participate in the state or local standards; however, participation for any given student may require alterations to the common standards and assessments. Decisions to make such alterations must have a compelling educational justification and must be made on an individual basis.
Recommendation 3. The committee recommends strengthening the IEP process as the formal mechanism for deciding how individual students with disabilities will participate in standards-based reform.

Although these recommendations address critical topics, they do not highlight some of the key lessons that have been learned about including students with disabilities in standards-based reform. I share some of the key lessons here.

Participation in assessments is only the first stepit is an important step, but not the most important goal of standards-based reform.

Low expectations and the belief that students with disabilities should be protected from harm continue to characterize too many special educators, creating a great disservice to students who will have to function in employment and postsecondary settings when they leave school. Standardsbased reform, of course, focuses on much more than just assessments. Key elements include the following:

- Goals (content standards)

- Indicators of success (performance standards)

- Measures of progress

- Reporting

- Consequences

The measures of progress are the assessments, clearly just one piece of the picture. The most critical piece is the notion that we provide all students with the opportunity to learn. For students with disabilities, this often means access to the general education curriculum first, then the provision of accommodations during instruction to ensure equal access to the general curriculum.

One of the notions behind participation in assessments is that we cannot know how students are progressing unless we have data to show us that performance. A common argument is that state and district assessments are not the best way to measure student performance, and that for students with disabilities, it is better to continuously measure student progress toward achieving the goals noted on their IEPs. This argument has created difficulties for special education because it has resulted in the field having little meaningful data on the performance of students (McGrew, Vanderwood, Thurlow, \& Ysseldyke, 1995). And it has created a situation in which it is easy to think that everything is okay and that any amount of progress is all right. This is not the case. Most students with disabilities should be meeting the same high standards as other students. We are unlikely to realize this goal unless instruction is significantly ratcheted up and directed toward the learning needs of students who are receiving special education services. 
Accountability is the key to standards-based reform for all students. Anecdotal evidence has been accumulating for some time about the expectations held for students receiving special education services. This evidence suggests that special educators have low expectations for students with disabilities. Some special educators also hold the attitude that they are more devoted to their students and know better than anyone else how to protect them and care for them. This attitude is a disservice to students with disabilities.

One of the advantages of standards-based reform is that it points out the inappropriateness of too much protection. It also begins to challenge the low expectations that have been held for many students with disabilities by showing what they know and can do.

Views on accommodations reflect attitudes-

accommodations are a key part of access to assessments, yet they are shrouded in conflicting attitudes.

Views about accommodations perhaps are one of the most telling indicators of individual views about including all students in standards-based reforms. For years we have respected assessments that have sterilized the information we collect on students: Everyone must perform under exactly the same conditions so we then can compare them to each other. A standards-based system looks at progress toward standards; it is not about comparing students to each other. Yet, we are unwilling to give up the old model of assessment, which, of course, then makes it more difficult to be accepting of accommodations.

To some extent, views on accommodations seem to reflect tolerance for differences. They also reflect, to some extent, views on how people work as adults. Today increasing numbers of accommodations are provided as natural supports for individuals to be successful in employment settings. These accommodations, furthermore, often are provided to all employees, not just those who have disabilities. Should our assessment system not reflect the conditions under which we expect individuals to work after they have left the educational system-that is, with the availability of lifelong accommodations?

The extent to which students are using accommodations during assessments also highlights some instructional problems. When NCEO began to talk about needed assessment accommodations, the link to instructional accommodations was apparent. If students are surprised by being provided an assessment accommodation to which they have never been exposed before, it likely will be of little help, and may actually be a hinderance to performance. Most state policies on accommodations now refer back to what happens during instruction (Thurlow, House, et al., 2000). Yet, we find that teachers' knowledge about how to identify and use instructional accommodations is limited (DeStefano \& Shriner, in press; Fuchs, Fuchs, Eaton, Hamlett, \& Karns, 2000; Scott, Vitale, \& Master, 1998).

\section{Consequences create complications-}

incentives to exclude students continue to exist and often are bolstered by high stakes accountability.

Accountability or, rather, counting all students equally is going to be the force that drives forward the benefits of standards-based reform for students with disabilities. Until students with disabilities count in the same way as other students do, it is too easy to discount their performance, and in discounting, to ignore it and the instructional need it identifies.

IDEA 97 required that students with disabilities be included in assessments, and that their performance be reported publicly in the same way and with the same frequency as performance is reported for other students. Even though states are having difficulty meeting the reporting requirement (Thurlow, Nelson, et al., 2000), that requirement is not really enough. Today's schools are driven by accountability systems that produce significant rewards or sanctions for the schools (Education Commission of the States, 1999)-teachers receive cash awards, schools lose their accreditation, and so on-all on the basis of student performance. These systems existed in 40 states in 1999 , and the number is likely increasing.

Children who count in these high-stakes systems are the ones who most likely will be attended to first. For this reason, students with disabilities must not only participate in assessments and have their scores reported, but their scores must count just like those of other students. Is this happening? Analyses (Krentz, Thurlow, \& Callender, 2000) suggest that finding out who exactly counts in state accountability formula is difficult - if you can even find the formulas being used for accountability. This is a huge gap in ensuring that all students have exposure to high standards and that they benefit from educational reforms. Unfortunately, as in the past, the students most likely to be left out are those with disabilities (along with those students of limited English proficiency).

Policy has outpaced the technology of standards-based education and assessment.

Policies surrounding the participation of students with disabilities in assessments, their access to the general education curriculum, and their inclusion in Title I services and evaluation systems have moved forward rapidly during the past decade. The policies have moved forward so rapidly that educators are still catching up. But not only educators 
are having to catch up. The test development industry is having to catch up as well. Test developers and publishers have not retooled their assessment instruments either to be accessible to all students or to be standardized appropriately with all students (along with their accommodation needs) included.

Technology is beginning to catch up to policy. For example, CTB-McGraw Hill's (2000) guidelines on accommodations are way ahead of the current thinking of most test publishers, at least in comparison to the information provided on accommodations in their test manuals.

There still is a need to go farther, however. At the time that items are developed, all students should be considered. I suspect that if items were developed to be more accessible to all students, the need for accommodations would be less. In addition, at the time of item reviews, a trained disability representative should participate on the bias review team to identify any nonaccessible items the item developers produced. This person has to be trained so inaccessibility can be identified for the entire range of disabilities. NCEO currently is in the process of putting together a manual that could be used to train individuals for participation on bias review teams and that item developers also could use.

\section{The bottom line-instruction!}

This lesson regarding the importance of instruction probably has come through already in the other lessons I have identified. It is an important lesson, however, and deserves repetition. As we have come to realize that students must be included in standards-based reform and as we have pushed students into assessments from which they were previously excluded, we have taken many side trails (including cheating), in an attempt to avoid the most important path of all: Students must receive appropriate instruction, characterized both by access to the general education curriculum and by appropriate accommodations. The instruction must reflect high expectations and data-based instructional corrections. Students with disabilities must have access to all the remedial and honors programs to which other students have access.

We have come a long way in the past decade. Although there are indications of changes in instruction as a result of the emphasis on standards and participation in state and district assessments, we still have a way to go. As we proceed through the next decade, the challenge remains to move beyond simply participation to full-blown success through comprehensive, inclusive, standards-based education for all students.

\section{REFERENCES}

American Federation of Teachers. (1996). Making standards matter 1996: An annual fifty-state report on efforts to raise academic standards. Washington, DC: Author.
American Federation of Teachers. (1999). Making standards matter 1999 Washington, DC: Author.

Anderson, N.E., Jenkins, F.F.. \& Miller, K.E. (1996). NAEP inclusion criteria and testing accommodations: Findings from the NAEP 1995 field test in mathematics. Princeton, NJ: Educational Testing Service.

Bielinski, J., \& Ysseldyke, J. (2000). Interpreting trends in the performance of special education students. Minneapolis: National Center on Educational Outcomes.

Bradley, A. (2000, Jan 13). The gatekeeping challenge. Quality counts 2000: Who should teach? (Education Week), 19(18), pp. 20, 22-24, 26.

Business Roundtable. (1996). A business leader's guide to setting academic standards. Washington, DC: Author.

CTB/McGraw-Hill. (2000). Guidelines for using the results of standardized tests administered under nonstandard conditions. Monterey. CA: Author.

David, J.M. (1997). The role of standards-based assessment in schoolwide instructional improvement: Necessary, perhaps, but not sufficient. Paper presented for New Standards Evaluation Steering Committee (cited in Elmore \& Rothman, 1999 Testing, Teaching and Learning, p. 76.

DeStefano, L., \& Shriner, J.G. (in press). The role of teacher decision-making in participation and accommodation of students with disabilities in large-scale assessments. Exceptional Children.

Education Commission of the States. (1999). Education accountability in 50 states. Denver: Author.

Elliott, J.L., Bielinski, J., Thurlow, M.L., DeVito, P., \& Hedlund, E. (1999). Accommodations and the performance of all students on Rhode Island's performance (Rhode Island Report 1). Minneapolis: University of Minnesota, National Center on Educational Outcomes.

Elliott, J.L., Erickson, R.N.. Thurlow, M.L., \& Shriner. J. (2000). Statelevel accountability for the performance of students with disabilities: Five years of change? Journal of Special Education, 34(1), 39-47.

Elliott, J.L., \& Thurlow, M.L. (2000). Improving test performance of students with disabilities on district and state assessments. Thousand Oaks, CA: Corwin Press.

Elmore, R.F., \& Rothman, R. (1999). Testing, teaching, and learning: A guide for states and school districts. Washington, DC: National Academy of Sciences.

Erickson, R.N., Thurlow, M.L., \& Ysseldyke, J.E. (1996). Neglected numerators, drifting denominators, and fractured fractions (Synthesis Report 23). Minneapolis: University of Minnesota, National Center on Educational Outcomes.

Erickson, R., Ysseldyke, J., \& Thurlow, M. (1997). Neglected numerators, drifting denominators, and fractured fractions: Determining participation rates for students with disabilities. Diagnostique, 23(2), 105-115.

Erickson, R., Ysseldyke, J., Thurlow, M., \& Elliott, J. (1997). Reporting educational results for students with disabilities (NCEO Policy Directions 8). Minneapolis: University of Minnesota, National Center on Educational Outcomes.

Fordham Foundation. (2000). The state of state standards 2000. Washington, DC: Thomas H. Fordham Foundation.

Fuchs, L.S., Funchs, D., Eaton, S.B., Hamlett, C.L., \& Karns, K.M. (2000). Supplementing teacher judgments of mathematics test accommodations with objective data sources. School Psychology Review, 29(1), 65-85.

Guy, B., Shin, H., Lee, S.Y., \& Thurlow, M.L. (1999). State graduation requirements for students with and without disabilities (Technical Report 24). Minneapolis: University of Minnesota, National Center on Educational Outcomes.

Heubert, J., \& Hauser, R. (1999). High stakes: Testing for tracking, promotion, and graduation. Washington, DC: National Academy Press.

Heumann, J.E., \& Warlick, K.R. (2000, Aug. 24). Questions and answers about provisions in the Individuals with Disabilities Education Act 
Amendments of 1997 related to students with disabilities and state and district-wide assessments (Memorandum to State Directors of Special Education, OSEP 00-24). Washington, DC: Office of Special Education Programs.

Hofmeister, A.M. (1993). Elitism and reform in school mathematics. Remedial \& Special Education, 14(6), 8-13.

Ingels, S.J. (1993). Strategies for including all students in national and state assessments: Lessons from a national longitudinal study. Paper presented at National Conference on Large-Scale Assessment, Albuquerque, NM. (ERIC Reproduction Service No. ED 363-645)

Ingels, S.J. (1996). Sample exclusion in NELS:88: Characteristics of base vear ineligible students; changes in eligibility status after four years (NCES Technical Report 96-723). Washington, DC: U.S. Department of Education, Office of Educational Research and Improvement.

Ingels, S.J., \& Scott, L.A. (1993). Exclusion of students with barriers to participation in NELS:88-Baseline excluded students two and four years later. Paper presented at annual meeting of American Educational Research Association, Atlanta. (ERIC Document Reproduction Service No. ED 360-371)

Keller, B. (2000, April 12). More N.Y. special education students passing state tests. Education Week on the Web (http://www.edweek.org/ ewstory.cfm?slug $=31$ ny.h 19 \&keywords=new $\% 20$ york $)$.

Kohn, A. (2000). Burnt at the high stakes. Joumal of Teacher Education. $5 /(4), 315-327$.

Koretz, D. (1997). The assessment of students with disabilities in Kentucky (CSE Technical Report 431). Los Angeles: National Center for Research on Evaluation, Standards, and Student Testing.

Krentz. J., Thurlow, M., \& Callender, S. (2000). Accountability systems and counting students with disabilities (Technical Report). Minneapolis: University of Minnesota. National Center on Educational Outcomes.

Linn, R.L. (2000). Assessments and accountability. Educational Researcher, $29(2), 4-16$.

Linn, R.L.. \& Herman, J.L. (1997). Standards-led assessment: Technical and policy issues for meaningful school and student progress (CSE Technical Report 426). Los Angeles: University of California, CRESST.

Mazzeo, J., Carlson, J.E., Voekl, K.E., \& Lutkus, A.D. (2000). Increasing the participation of special needs students in NAEP: A report on 1996 NAEP research activities (NCES Statistical Analysis Report 2000473). Washington, DC: U.S. Department of Education, Office of Educational Research and Improvement.

McDonnell, L.. McLaughlin, M., \& Morison, P. (1997). Educating one \& all: Students with disabilities and standards-based reform. Washington. DC: National Academy Press.

McGrew, K. S., Algozzine, B., Ysseldyke, J. E., Thurlow, M. L.. \& Spiegel, A. N. (1995). The identification of individuals with disabilities in national databases: Creating a failure to communicate. Journal of Special Education, 28 (4), 472-487.

McGrew, K.S.. Thurlow, M.L. Shriner, J.G.. \& Spiegel, A.N. (1992). Inclusion of students with disabilities in national and state data collection systems (Technical Report 2). Minneapolis: University of Minnesota. National Center on Educational Outcomes.

McGrew. K.S., \& Vanderwood, M. (1993). The identification of people with disabilities in national data bases: A failure to communicate (Technical Report 6). Minneapolis: University of Minnesota, National Center on Educational Outcomes.

McGrew, K.S., Vanderwood, M., Thurlow, M.L., \& Ysseldyke, J.E. (1995). Why we can's say much about the statutes of status of students with disabilities during educational reform (Synthesis Report 21). Minneapolis: University of Minnesota, National Center on Educational Outcomes.

National Association of State Boards of Education. (1998). The numbers game: Ensuring quantity and quality in the teaching workforce. Alexandria, VA: Author.
National Council on Education Standards and Testing. (1992). Raising standards for American education. Washington, DC: U.S. Government Printing Office.

National Council of Teachers of Mathematics. (1989). Curriculum and education standards for school mathematics. Reston, VA: Author.

National Research Council. (1993). National science education standards. Washington, DC: National Committee on Science Education Standards and Assessment.

Newmann, F.M., \& Associates. (1996). Authentic achievement: Restructuring schools for intellectual quality. San Francisco: Jossey-Bass.

Olson, J.F., Bond, L., \& Andrews, C. (1999). Data from the armual survev: State student assessment programs. Washington, DC: Council of Chief State School Officers.

Olson. L. (2000, May 31). Indiana case focused on special ed. Education Week on the Web thttp://wwwedweek,orglewstory.cfm? slug=38states hlo8kewords=Indiana\%20special \%20education).

Scott. B.J.. Vitale, M.R., \& Master. W.G. (1998). Implementing instructional adaptations for students with disabilities in inclusive classrooms: A literature review. Remedial \& Special Education, 19(2), 106-119.

Shepard, L.A. (1991). Will national tests improve student learning? Los Angeles: University of California, CRESST.

Shriner, J.G., Kim, D.. Thurlow, M.L., \& Ysseldyke, J.E. (1992). IEPs and standards: What they say for students with disabilities (Technical Report No. 5). Minneapolis: University of Minnesota, National Center on Educational Outcomes.

Shriner, J.G., \& Thurlow, M.L. (1992). Special education outcomes 1991. Minneapolis: University of Minnesota. National Center on Educational Outcomes.

Spillane, J.P. (1997). External reform initiatives and teachers' efforts to reconstruct their practice: The mediating role of teachers zones of enactment. Paper presented at annual meeting of Association for Public Policy Analysis and Management (cited in National Research Council, 1999, pp. 75-76).

State policy updates (2000, Jan. 13). Quality counts 2000: Who should teach? (Education Week), 19 (18).

Thompson, S.J., \& Thurlow, M.L. (1999). 1999 State special education outcomes. Minneapolis: University of Minnesota, National Center on Educational Outcomes.

Thurlow, M.L. (in press). Focusing on state and local assessments. ALERTS.

Thurlow, M.L.. Elliott, J.L., \& Ysseldyke, J.E. (1998). Testing students with disabilities: Practical strategies for complying with district and state requirements. Thousand Oaks, CA: Corwin Press.

Thurlow, M.L., House, A., Boys, C., Scott, D., \& Ysseldyke, J. (2000). State assessment policies on participation and accommodations for students with disabilities: 1999 update (Synthesis Report 33). Minneapolis: University of Minnesota, National Center on Educational Outcomes.

Thurlow, M.L., \& Johnson, D.R. (2000). High stakes testing of students with disabilities. Journal of Teacher Education, 5l(4), 305-314.

Thurlow, M., Langenfeld, K.. Nelson, J.R., Shin, H., \& Coleman, J. (1998). State accountability reports: What are states saying about students with disabilities? (Technical Report 20). Minneapolis: University of Minnesota, National Center on Educational Outcomes.

Thurlow, M.L.. Nelson, J.R., Teelucksingh, E., \& Ysseldyke, J.E. (2000). Wheres Waldo? A third search for students with disabilities in state accountability reports (Technical Report 25). Minneapolis: University of Minnesota. National Center on Educational Outcomes.

Thurlow, M. L., Scott. D. L., \& Ysseldyke, J. E. (1995a). A compilation of states' guidelines for accommodations in assessments for students with disabilities (Synthesis Report 18). Minneapotis: University of Minnesota, National Center on Educational Outcomes. 
Thurlow, M. L., Scott, D. L.. \& Ysseldyke. J. E. (1995b). A compilation of states' guidelines for including students with disabilities in assessments (Synthesis Report 17). Minneapolis: University of Minnesota, National Center on Educational Outcomes.

Thurlow, M., \& Thompson, S. (2000). Diploma options and graduation policies for students with disabilities (NCEO Policy Directions 10). Minneapolis, MN: University of Minnnesota, National Center on Educational Outcomes.

Thurlow, M.L., \& Ysseldyke, J.E. (2000). Standard-setting challenges for special populations. In G. Cizek (Ed.), Standard setting on peformance assessments (Ch. 12). Mahwah, NJ: Lawrence Erlbaum Associates.

Thurlow, M., Ysseldyke, J., Gutman, S.. \& Geenen, K. (1998). An analysis of inclusion of students with disabilities in state standards documents (Technical Report 19). Minneapolis: University of Minnesota, National Center on Educational Outcomes.

Thurlow, M. L., Ysseldyke, J. E., \& Silverstein, B. (1993). Testing accommodations for students with disabilities: A review of the literature (Synthesis Report 4). Minneapolis: University of Minnesota, National Center on Educational Outcomes.

Trimble, S. (1998). Performance trends and use of accommodations on a statewide assessment (NCEO Assessment Series, Maryland/Kentucky Report 3). Minneapolis: University of Minnesota, National Center on Educational Outcomes.

U.S. Department of Education. (1995). Teacher supply; teacher qualifications, and teacher turnover, 1990-91. Washington, DC: National Center for Education Statistics.

U.S. Department of Education. (1999). Peer reviewer guidance for evaluating evidence of final assessments under Title I of the Elementary and Secondary Education Act. Washington, DC: Author.

Why Johnny stayed home. (1997. Oct. 6). Newsweek. 130 (34). 60.

Ysseldyke, J., Krentz, J., Elliott, J., Thurlaw, M., Erickson, R., \& Moore, M. (1998). NCEO framework for educational accountability. Minneapolis, MN: University of Minnesota, National Center on Educational Outcomes.

Ysseldyke, J.. Thurlow, M., \& Erickson, R. (1994a). Educational outcomes and indicators for grade 4. Minneapolis: University of Minnesota. National Center on Educational Outcomes.
Ysseldyke, J., Thurlow, M., \& Erickson, R. (1994b). Educational outcomes and indicators for grade 8. Minneapolis: University of Minnesota, National Center on Educational Outcomes.

Ysseldyke, J., Thurlow, M., Erickson, R., Gabrys. R., Haigh, J., Trimble, S., \& Gong, B. (1996). A comparison of state assessment systems in Maryland and Kentucky with a focus on the participation of students with disabilities (Maryland/Kentucky Report 1). Minneapolis: University of Minnesota, National Center on Educational Outcomes.

Ysseldyke, J., Thurlow, M., \& Gilman, C. (1993a). Educational outcomes and indicators for early childhood (age 3). Minneapolis: University of Minnesota, National Center on Educational Outcomes.

Ysseldyke, J., Thurlow. M., \& Gilman, C. (1993b). Educational outcomes and indicators for early childhood (age 6). Minneapolis: University of Minnesota, National Center on Educational Outcomes.

Ysseldyke, J., Thurlow, M., \& Gilman, C. (1993c). Educational outcomes and indicators for individuals at the post-school level. Minneapolis: University of Minnesota, National Center on Educational Outcomes.

Ysseldyke, J., Thurlow, M., \& Gilman, C. (1993d). Educational outcomes and indicators for students completing school. Minneapolis: University of Minnesota, National Center on Educational Outcomes.

Ysseldyke, J.E., Thurlow, M.L., Langenfeld. K.L., Nelson, J.R., Teelucksingh, E., \& Seyfarth, A. (1998). Educational results for students with disabilities: What do the data tell us? (Technical Report 23).

Ysseldyke, J.. Thurlow, M., McGrew, K. S., \& Shriner, J. G. (1994). Recommendations for making decisions about the participation of students with disabilities in statewide assessment programs (Synthesis Report 15). Minneapolis: University of Minnesota, National Center on Educational Outcomes.

Ysseldyke, J., Thurlow, M., McGrew, K., \& Vanderwood, M. (1994). Making decisions about the inclusion of students with disabilities in largescale assessments (Synthesis Report 13). Minneapolis: University of Minnesota, National Center on Educational Outcomes.

Ysseldyke, J.E., Thurlow, M.L., \& Shriner, J.G. (1992). Outcomes are for special educators too. Teaching Exceptional Children, 25, 36-50.

Zlatos, B. (1992). Don't test, don't tell: Is 'academic red-shirting' skewing the way we rank our schools? The American School Board. 191 (11. $24-28$.

\section{PERMISSIONS AND COPYRIGHT}

All rights are reserved. No part of this publication may be reproduced, photocopied, faxed, stored in a retrieval system, or transmitted in any form or by any means, electronic, mechanical, recording or otherwise, without the prior written permission of the publisher.
Back issues are available for sale. Reproduction requires permission and payment of fees. It is illegal and a violation of federal copyright law to reproduce this publication without permission. Direct all inquiries to the permissions editor. 